\title{
Organic phosphorus: potential solutions for phosphorus security
}

\author{
Philip M. Haygarth • Philippe Hinsinger • \\ Daniel Blackburn
}

Received: 30 April 2018 / Accepted: 4 May 2018/Published online: 23 May 2018

(C) Springer International Publishing AG, part of Springer Nature 2018

This special issue of Plant and Soil presents a collection of papers generated from the Organic Phosphorus Workshop that occurred in the Lake District of England in September 2016, with $\sim 100$ delegates in attendance (https://op2016.com/). This was the third in a series of such meetings, previously held in 2003 (Ascona, Switzerland; Turner et al. 2005) and more recently in 2013 (Panama City, Republic of Panama; Turner et al. 2015). Our aim was to assemble a contemporary snapshot of offered research papers in the subject area that also included some new reviews, reflections and commentaries that tried to challenge the subject and its progression. Accordingly, this editorial provides a brief opportunity to reflect on the range and scope of papers received and to put the subject into wider context; we will not provide an exhaustive discussion of all papers, instead wish to provide some context, as well as highlight some examples for our readers.

Responsible Editor: Hans Lambers.

P. M. Haygarth $(\bowtie)$

Lancaster Environment Centre, Lancaster University,

Lancaster LA1 4YQ, UK

e-mail: p.haygarth@lancaster.ac.uk

P. Hinsinger

Eco\&Sols, Univ Montpellier, CIRAD, INRA, IRD, Montpellier

SupAgro, Montpellier, France

D. Blackburn

Department of Soils, Water and Agricultural Engineering, College of Agricultural and Marine Sciences, Sultan Qaboos University, PO Box 34, Al-khod123 Sultan Qaboos, Sultanate of Oman
The essence of the organic phosphorus and the food security challenge is summarised in the introductory Marschner review provided by Menezes-Blackburn et al., providing a reflection on the state of the art as of 2017. The paper asks:

"Recent scientific efforts have been directed toward increasing the plant availability of this legacy soil $\mathrm{P}$ and enabling an efficient agronomic use of this important $\mathrm{P}$ reserves. But, how likely is legacy soil $\mathrm{P}$ to be a key source of $\mathrm{P}$ to sustain agricultural production? For how many growing seasons would legacy soil $\mathrm{P}$ be able to sustain crop production, and what yields may be expected? What are our most promising and sustainable agroecological innovations to accomplish this?"

Menezes-Blackburn et al. provide an interesting metaanalysis that uses a collation of the phosphorus stocks analysed from global literature of ${ }^{31} \mathrm{P}-\mathrm{NMR}$ data for agricultural soils, which eloquently reminds us that organic (diester and monoester) phosphorus forms typically represent around 30-40\% of total soil phosphorus. They strongly argue that organic phosphorus may represent a potentially utilizable reserve of phosphorus, accessible through innovation in the areas of biofertilizers, engineered plants and agricultural management practices. In many respects, this sets the context for the other types of papers that follow in the special issue.

We received 21 offered papers with 13 making it through peer review. The accepted manuscripts cover 
an appropriate range of topics related to organic phosphorus. This issue contains papers that we can class as 'reviews' (two papers, George et al. 2017 and MenezesBlackburn et al. 2017), 'plant centric' (Li et al. 2017 and Darch et al. 2017), 'soil centric' (three papers, Stahr et al. 2017; Missong et al. 2017 and Spain et al. 2018) 'microbial centric' (two papers Nassal et al. 2017 and Gaiero et al. 2017), 'analytical' (two papers, Adams et al. 2017 and Whitfield et al. 2017) and 'systems' (two papers - Boitt et al. 2017 and Neal et al. 2017). An additional historical overview paper has also been published from the Workshop (Haygarth et al. 2018). We encourage readers to absorb in detail the material provided and also make their own opinions from these papers.

We would like to highlight an innovative approach led by Tim George with the Worksop Committee, as it tried to collect data from the 'workshop' itself, involving the delegates as co-authors. This was evidently a great challenge as it represents the elicitation of $\sim 100$ experts that were corralled throughout the workshop from the George and the Workshop Commitee. To successfully engage so many researchers is potentially of great value to help progression of the subject and their collective viewpoint identified seven key opportunities for organic phosphorus research including:

- the need for integrated, quality controlled and functionally based methodologies;

- assessment of stoichiometry relationships of phosphorus with other elements in organic matter;

- understanding the dynamics of organic phosphorus in natural and managed systems;

- assessing the role of microorganisms in controlling organic phosphorus cycles;

- consideration of the implications of nanoparticles in the environment;

- the need for better modelling and understanding in systems context;

- improved outreach and communication of the organic phosphorus issues.

Each priority is discussed and a statement of intent for the organic phosphorus research community is made that highlights where there are key contributions to be made. Their table 1 provides a synthesis of the $\sim 100$ expert opinions on the global issues associated with organic phosphorus, and how the research community can potentially contribute solutions to these issues, and identification of opportunities for research to facilitate this. We would particularly like to highlight one of the final statements made by George et al. that suggests:

“organic phosphorus research has a critical role to play in tackling a number of important global challenges and there are key contributions to be made toward understanding biogeochemical cycles, dynamics and function of natural ecosystems and the management of agricultural systems..."

and further that:

"the key to fostering this change will depend on logically communicating the importance of organic phosphorus to society at large, engaging with stakeholders on important global issues, and ultimately pushing this important area of research up the agenda of policy makers and funding bodies on a global scale."

We hope that this collection of papers can help contribute to this.

\section{References}

Adams JL, Tipping E, Thacker SA, Quinton JN (2017) An investigation of the distribution of phosphorus between free and mineral associated soil organic matter, using density fractionation. Plant Soil. https://doi.org/10.1007/s11104-017-3478-4. (in this issue)

Boitt G, Black A, Wakelin SA, McDowell RW, Condron LM (2017) Impacts of long-term plant biomass management on soil phosphorus under temperate grassland. Plant Soil. https://doi.org/10.1007/s11104-017-3429-0. (in this issue)

Darch T, Giles CD, Blackwell MSA, George TS, Brown LK, Menezes-Blackburn D, Shand CA, Stutter MI, Lumsdon DG, Mezeli MM, Wendler R, Zhang H, Wearing C, Cooper P, Haygarth PM (2017) Inter- and intra-species intercropping of barley cultivars and legume species, as affected by soil phosphorus availability. Plant Soil. https://doi.org/10.1007 /s11104-017-3365-z. (in this issue)

Gaiero JR, Bent E, Fraser TD, Condron LM, Dunfield KE (2017) Validating novel oligonucleotide primers targeting three classes of bacterial non-specific acid phosphatase genes in grassland soils. Plant Soil. https://doi.org/10.1007/s11104-0173338-2. (in this issue)

George TS, Giles CD, Menezes-Blackburn D, Condron LM, Gama-Rodrigues AC, Jaisi D, Lang F, Neal AL, Stutter MI, Almeida DS, Bol R, Cabugao KG, Celi L, Cotner JB, Feng G, Goll DS, Hallama M, Krueger J, Plassard C, Rosling A, Darch T, Fraser T, Giesler R, Richardson AE, Tamburini F, 
Shand CA, Lumsdon DG, Zhang H, Blackwell MSA, Wearing C, Mezeli MM, Almås ÅR, Audette Y, Bertrand I, Beyhaut E, Boitt G, Bradshaw N, Brearley CA, Bruulsema TW, Ciais P, Cozzolino V, Duran PC, Mora ML, de Menezes AB, Dodd RJ, Dunfield K, Engl C, Frazão JJ, Garland G, González Jiménez JL, Graca J, Granger SJ, Harrison AF, Heuck C, Hou EQ, Johnes PJ, Kaiser K, Kjær HA, Klumpp E, Lamb AL, Macintosh KA, Mackay EB, McGrath J, McIntyre C, McLaren T, Mészáros E, Missong A, Mooshammer M, Negrón CP, Nelson LA, Pfahler V, Poblete-Grant P, Randall M, Seguel A, Seth K, Smith AC, Smits MM, Sobarzo JA, Spohn M, Tawaraya K, Tibbett M, Voroney P, Wallander H, Wang L, Wasaki J, Haygarth PM (2017) Organic phosphorus in the terrestrial environment: a perspective on the state of the art and future priorities. Plant Soil. https://doi.org/10.1007/s11104-017-3391-x. (in this issue)

Haygarth PM, Harrison AF, Turner BL (2018) On the history and future of soil organic phosphorus research: a critique across three generations. Eur J Soil Sci 69:86-94. https://doi. org/10.1111/ejss. 12517

Turner BL, Frossard E, Baldwin DS (2005) Organic phosphorus in the environment. CABI Pub, Wallingford ; Cambridge

Li M, Cozzolino V, Mazzei P, Drosos M, Monda H, Hu Z, Piccolo A (2017) Effects of microbial bioeffectors and $P$ amendements on $\mathrm{P}$ forms in a maize cropped soil as evaluated by $31 \mathrm{P}-\mathrm{NMR}$ spectroscopy. Plant Soil. https://doi. org/10.1007/s11104-017-3405-8. (in this issue)

Menezes-Blackburn D, Giles C, Darch T, George TS, Blackwell M, Stutter M, Shand C, Lumsdon D, Cooper P, Wendler R, Brown L, Almeida DS, Wearing C, Zhang H, Haygarth PM (2017) Opportunities for mobilizing recalcitrant phosphorus from agricultural soils: a review. Plant Soil. https://doi. org/10.1007/s11104-017-3362-2. (in this issue)
Missong A, Bol R, Nischwitz V, Krüger J, Lang F, Siemens J, Klumpp E (2017) Phosphorus in water dispersible-colloids of forest soil profiles. Plant Soil. https://doi.org/10.1007 /s11104-017-3430-7. (in this issue)

Nassal D, Spohn M, Eltlbany N, Jacquiod S, Smalla K, Marhan S, Kandeler E (2017) Effects of phosphorus-mobilizing bacteria on tomato growth and soil microbial activity. Plant Soil. https://doi.org/10.1007/s11104-017-3528-y. (in this issue)

Neal AL, Blackwell M, Akkari E, Guyomar C, Clark I, Hirsch PR (2017) Phylogenetic distribution, biogeography and the effects of land management upon bacterial non-specific Acid phosphatase Gene diversity and abundance. Plant Soil. https://doi.org/10.1007/s11104-017-3301-2. (in this issue)

Spain AV, Tibbett M, Ridd M, McLaren TI (2018) Phosphorus dynamics in a tropical forest soil restored after strip mining. Plant Soil. https://doi.org/10.1007/s11104-018-3668-8. (in this issue)

Stahr S, Graf-Rosenfellner M, Klysubun W, Mikutta R, Prietzel J, Lang F (2017) Phosphorus speciation and C:N:P stoichiometry of functional organic matter fractions in temperate forest soils. Plant Soil. https://doi.org/10.1007/s11104-017-3394-7. (in this issue)

Turner BL, Cheesman AW, Condron LM, Reitzel K, Richardson $\mathrm{AE}$ (2015) Introduction to the special issue: developments in soil organic phosphorus cycling in natural and agricultural ecosystems. Geoderma 257:1-3 https://doi.org/10.1016/j. geoderma.2015.06.008

Whitfield H, Riley AM, Diogenous S, Godage HY, Potter BVL, Brearley CA (2017) Simple synthesis of 32P-labelled inositol hexakisphosphates for study of phosphate transformations. Plant Soil. https://doi.org/10.1007/s11104-017-3315-9. (in this issue) 